\title{
Friendship Traditions in the New Testament: An Overview
}

(This is the draft submitted to, and accepted for publication in Pacifica, to appear in 2017. Not for reproduction or citation. If citing, please use the final published version)

\section{Introduction}

This article surveys the extent and nature of the deployment of friendship traditions in the texts of the New Testament. ${ }^{1}$ The discussion of relevant texts is predicated on the assumption that, as is the case with other 'themes' in New Testament theology and ethics, we should not limit ourselves to the study of those places where specific lexical terms relevant to the enquiry are deployed. ${ }^{2}$ The specific Greek word for friendship are used rarely in the New

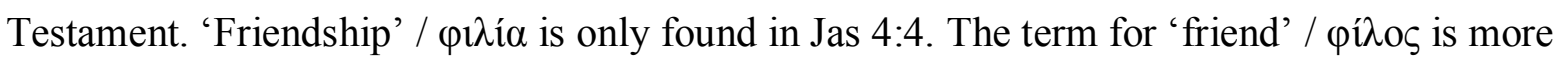
commonly encountered, especially in the Jesus tradition, but the level of connection to antecedent friendship traditions is often less than explicit. ${ }^{3}$ The point applies equally to the repeated use of the verb 'to love' / $\varphi \imath \lambda \varepsilon ́ \omega$ and related terms in the New Testament. ${ }^{4}$ In the same way that the presence of the term in Luke 7:6 ('the centurion sent friends') does not

\footnotetext{
${ }^{1}$ In many ways this article therefore covers similar ground to that of Alan C. Mitchell, "“"Greet the Friends by Name": New Testament Evidence for the Greco-Roman Topos on Friendship," in Greco-Roman Perspectives on Friendship, ed. John T. Fitzgerald, SBL Resources for Biblical Study 34 (Atlanta: Scholars, 1997), $225-262$. Mitchell's comprehensive discussion is directed at elucidating the way that New Testament texts 'contribute to the friendship tradition' (p.225). This article focusses on the contribution that friendship traditions make to the theology and ethics of the New Testament.

${ }^{2}$ Equivalent examples might be the relative lack of specifically 'covenantal' language in the New Testament, or the relative reluctance to employ the conventional language of 'virtue' in the context of ethical reflection. In both instances, the absence of specific lexical terms tells us too little about the extent of the influence of Jewish covenantal thought, or patterns of Greco-Roman moral reasoning, on the authors of the relevant early Christian texts. In passing we note that covenant ideas and ethical paraenesis are closely aligned with the likely presence of friendship topoi in a number of New Testament texts.

${ }^{3}$ See Matt 11:19; Luke 7:6, 34; 11:5-6, 8; 12:4; 14:10, 12; 15:6, 9, 29; 16:9; 21:16; 23:12; John 3:29; 11:11; 15:13-15; 19:12; Acts 10:24; 19:31; 27:3; James 2:23; 4:4; 3 John 1:15.

${ }^{4}$ The terms $\varphi 1 \lambda \alpha \delta \varepsilon \lambda \varphi \dot{\alpha} \alpha$ (Rom 12:10; 1 Thess 4:9; Heb 13:1; 1 Pet 1:22; 2 Pet 1:7) and $\varphi 1 \lambda \alpha ́ \delta \varepsilon \lambda \varphi o \varsigma(1$ Pet 3:8) are terms of fictive kinship. See the discussion of the Pauline evidence in Reidar Aasgaard, 'My Beloved Brothers and Sisters': Christian Siblingship in Paul, Journal for the Study of the New Testament/Early Christianity in Context 265, (London / New York: T \& T Clark International, 2004).
} 
necessarily suggest the influence of traditions of friendship, the absence of specifically friendship vocabulary from Paul's letter to the Philippians does not necessarily imply its absence. We must look for broader patterns of language and argumentation, within which we may be able to identify specific terms, motifs, or topoi, that indicate the adoption or adaptation of historically and culturally available patterns of construing human relations.

We also do well not to limit ourselves to the available Greco-Roman sources for friendship. There is a strong likelihood that, in some cases, the New Testament's account of friendship within the community, or between believers and God, is mediated through biblical and $2^{\text {nd }}$ Temple Jewish sources. Of course, many of these texts and traditions are themselves the product of the intercultural encounter between 'Judaism' and 'Hellenism'. 5 I hope to show, however, that at certain points it is this Hellenistic Jewish construal of friendship (directed especially towards articulation the nature of humanity's relationship to God) that is evident in patterns of early Christian thought. Given the extensive amount of scholarly literature available on these traditions, I highlight those works that have appeared since Mitchell's 1997 article, as well as those that have a particular bearing on the interpretation of the New Testament texts here surveyed. ${ }^{6}$ Before turning to the New Testament, a brief overview of these Greco-Roman and Jewish traditions is in order.

\section{Greco-Roman Friendship Traditions ${ }^{7}$}

\footnotetext{
${ }^{5}$ Specifically, the evidence of Sirach, Wisdom of Solomon and Philo points clearly to the combination of Greek ethical ideals with biblical traditions.

${ }^{6}$ See n. 1 above.

${ }^{7}$ I have avoided any extensive treatment of the primary evidence (mostly made up of literary texts) in support of the summary statements here. For a full analysis see the essays in John T. Fitzgerald, ed., Friendship, Flattery, and Frankness of Speech: Studies on Friendship in the New Testament World, 82 (Leiden: Brill, 1996), John T. Fitzgerald, ed., Greco-Roman Perspectives on Friendship, SBL Resources for Biblical Study 34 (Atlanta: Scholars, 1997), Michael Peachin, ed., Aspects of Friendship in the Graeco-Roman World: Proceedings of a Conference Held at the Seminar für Alte Geschichte, Heidelberg, on 10-11 June 2000, Journal of Roman Archaeology Supplementary Series 43 (Portsmouth RI: Journal of Roman Archaeology, 2001), and the surveys
} 
The language of friendship emerges in Greek literature as a way of describing forms of intimate association between two or more people. ${ }^{8}$ While the etymology of the $\varphi 1 \lambda$ - root, and the earliest connotations of the terms (either as a term indicating possession : 'belonging to me', or affection: 'loved by me') are debated, it is clear that as early as Homer the notion of friendship is operative and already combines elements of both the possessive and affective senses. ${ }^{9}$ In the earliest stages of the tradition we can see several themes emerging, which later are subjected to detailed explanation in more systematic treatments of friendship, which in both republican and imperial Rome solidifies into a recognizable form of social relationship. ${ }^{10}$ These include:

1. Similarity in 'thinking', 'feeling' or 'purpose': evoked through the commonplace of having the 'same mind.

2. Relating to the other through 'frank speech' rather than 'flattery'.

3. The importance of reciprocation and mutual obligation.

4. Consideration of appropriate levels of affection between friends.

5. The need for mutual loyalty and trust

6. The possibility of disloyalty and the breaking of the bonds of friendship leading to reflections on the relationship between friendship and its opposite: enmity

\footnotetext{
in Johns Varghese, The Imagery of Love in the Gospel of John, Analecta Biblica 177, (Rome: Gregorian \& Biblical, 2009), 207-234 and Alicia J. Batten, Friendship and Benefaction in James, Emory Studies in Early Christianity 15, (Blandford Forum: Deo, 2010). For the Latin tradition see especially Craig A. Williams, Reading Roman Friendship, (Cambridge: Cambridge University Press, 2012).

${ }^{8}$ The pre-Aristotelian material is surveyed in John T. Fitzgerald, "Friendship in the Greek World Prior to Aristotle," in Greco-Roman Perspectives on Friendship, ed. John T. Fitzgerald, SBL Resources for Biblical Study 34 (Atlanta: Scholars, 1997), 13-34, with a focus on Homer and reference to earlier scholarship (see especially p.14, n.3).

${ }^{9}$ Fitzgerald, "Friendship," 15-21.

${ }^{10}$ For an overview of the range of social relations beyond the family see Peter Garnsey and Richard Saller, The Roman Empire: Economy, Society and Culture, (London: Duckworth, 1987), 148-159.
} 
While scholars disagree about the relative significance of each of these factors for understanding friendship in the classical world, the list provides us with a rough set of criteria against which we can analyze early Christian texts with a view to identifying the relative influence of friendship traditions upon them.

The notions of friendship that develop in this tradition have the question of interpersonal relationships at their core. Yet, friendship relations have significance beyond that which is true for the parties involved. John Fitzgerald notes that what begins as a way of accounting for the nature of relationships between two individuals (Achilles and Patroclus, for example) emerges as a key resource for articulating the nature of appropriate social relations in the Greek polis. Crucial to this development is, of course, the work of Aristotle whose extensive treatment of friendship in the Nicomachean and Eudemian Ethics has been the focus of an enormous body of scholarly discussion. Aristotle's ascending taxonomy of friendship into the

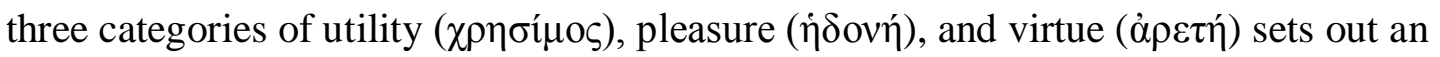
influential framework for understanding the ethical motivations and goals inherent to friendship relations, and also sets friendship into a telic scheme by which those relationships can aspire to an idealized condition. ${ }^{11}$ Friendships based on virtue encompass pleasure and utility, but because they are based on a shared pursuit of the good, have a permanency and a 'perfection' that mean that they will inevitably be rare. ${ }^{12}$ Thus, for Cicero, friendship consists in 'accord in all things, human and divine, conjoined with mutual goodwill and affection...no better thing has been given to man by the immortal gods'. ${ }^{13}$ Plutarch shares the same, near

\footnotetext{
${ }^{11}$ Eth. nic. 8.3.1-6 (1156a-b).

${ }^{12}$ Eth. nic. 8.3.7-9 (1156b).

${ }^{13}$ Amic. 6.20. Translation in Cicero, De Senectute, de Amicitia, de Divinatione, Loeb Classical Library 154, trans. William Armistead Falconer. (Cambridge / London: Harvard University Press / William Heinemann, 1923), 131. For a discussion of Cicero see Benjamin Fiore SJ, "The Theory and Practice of Friendship in
} 
utopian, view: 'in our friendship's consonance and harmony there must be no element unlike, uneven, or unequal, but all must be alike to engender agreement in words, counsels, opinions, and feelings, and it must be as if one soul were apportioned among two or more bodies.' ${ }^{14}$

It is worth considering the likely basis for the claim that such ideas might have been known and appealed to by the authors of the New Testament. On the one hand the centrality of friendship as an available category for understanding a wide variety of human relationships is clearly established. As a concept that continued to reflect its early possessive connotation ('someone who belongs to me'), and that was therefore used to describe various kinds of kinship, tribal, and political associations, it was in easy reach for authors seeking to construct common identity and mutual solidarity for the emerging Christian movement in the context of classical antiquity. Yet, there is probably more to it than that. David Konstan has demonstrated that earlier scholarship on Greco-Roman friendship took a wrong turn in downplaying its affective dimensions, and as a result neglected to see how friendship provided a means of construing patterns of sociality beyond obligation. Friendship, for Konstan, provided 'a space for sympathy and altruism...that stands as an alternative to structured forms of interaction based on kinship, civic identity, or commercial activity.' ${ }^{15}$ Friendship provided, potentially at least, a way of directing early Christian identity and

Cicero," in Greco-Roman Perspectives on Friendship, ed. John T. Fitzgerald, SBL Resources for Biblical Study 34 (Atlanta: Scholars, 1997), 59-76. Note also the development of Aristotle's taxonomy in Arius Didymus (a teacher of Augustus) for whom friendship is to be universally applied in the model of Stoic oikeiôsis. See the discussion in Frederic M. Schroeder, "Friendship in Aristotle and Some Peripatetic Philosophers," in GrecoRoman Perspectives on Friendship, ed. John T. Fitzgerald, SBL Resources for Biblical Study 34 (Atlanta: Scholars, 1997), 35-57, here p.49-53.

${ }^{14}$ Amic. mult. 8 (Moralia 96.E-F). Translation in Plutarch, Moralia, Volume II: How to Profit by One's Enemies. On Having Many Friends. Chance. Virtue and Vice. Letter of Condolence to Apollonius. Advice About Keeping Well. Advice to Bride and Groom. The Dinner of the Seven Wise Men. Superstition., Loeb Classical Library 222, trans. Frank Cole Babbitt. (Cambridge MA: Harvard University Press, 1928), 66-67.

${ }^{15}$ David Konstan, Friendship in the Classical World, Key Themes in Ancient History (Cambridge: Cambridge University Press, 1997), 6. 
solidarity to particular ends consonant with the particularity and shape of the kerygma: love, altruism, self-giving, and 'other-regard'.

There is one further aspect of the classical friendship tradition that is relevant to the study of early Christian usage. In a few of the sources the idealization of human friendship is closely connected to the divine realm: friendship is a gift from the gods, or a reflection of the divine. ${ }^{16}$ But this theme lies undeveloped. The specific notion of friendship between God/the gods and humanity is an aspect that emerges with much greater clarity in Jewish discussions of friendship. ${ }^{17}$

\section{Jewish Friendship Traditions}

Saul Olyan has recently published a major study of Jewish understandings of friendship which is essential reading and on which I have heavily relied for the comments that follow. ${ }^{18}$ The multi-faceted portrayal of friendship in the Hebrew Bible preserves a distinctive account of both the possessive and affective dimensions that I noted above. Olyan provides a working definition as follows: 'ideally friendship is a relationship between people who choose to associate or affiliate with one another and...involves positive feelings described by texts as

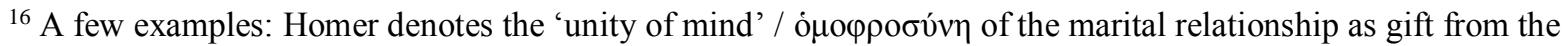
gods (Od. 6.180-185); Pythagorean 'harmony' which begins in God, comes to expression in human friendship (Diog. Laert. 8.33); in Cicero, friendship of the ideal kind is so rare as to render it 'almost divine' / paene divino (Amic. 17.64).

${ }^{17}$ Konstan notes that 'Christians outdid the classical tradition in recognizing the possibility of friendship between mortals and God or angels' (Friendship, 167). The works of $3^{\text {rd }}$ century CE teacher Iamblichus seem to contain a Neoplatonic version of the idea: see Johan C. Thom, ""Harmonious Equality" The Topos of Friendship in Neopythagorean Writings," in Greco-Roman Perspectives on Friendship, ed. John T. Fitzgerald, SBL Resources for Biblical Study 34 (Atlanta: Scholars, 1997), 77-103, here 98-103.

${ }^{18}$ Saul M. Olyan, Friendship in the Hebrew Bible, Anchor Yale Bible Reference Library (New Haven: Yale University Press, 2017).
} 
"love". ${ }^{19}$ The texts that describe or evoke friendship relations speak of forms of intimacy and unity other than those provided by ties of family or kin (see Deut 13:7; Psa 55:14; Prov 18:24). ${ }^{20}$ Reciprocity and mutual obligation are central to the maintenance of the relationship (Psa 35:13-14) and the real possibility of disloyalty, of friends becoming enemies, is explored. ${ }^{21}$

The relationship between friendship language and Jewish covenantal thinking, noted by Olyan, is significant for understanding the New Testament. ${ }^{22}$ Notably, the relationship between Ruth and Naomi ('characterized by choice, mutual affection, and behavioural parity') is described in terms that re-direct the covenant treaty between God and Abraham/Israel towards the horizontal friendship between the two women:

"Do not press me to leave you or to turn back from following you!

Where you go, I will go;

Where you lodge, I will lodge; your people shall be my people, and your God my God.” (Ruth 1:16) ${ }^{23}$

Ben Sira's treatment of friendship has been extensively discussed, most recently by Olyan who documents the continuity from the traditions of the Hebrew Bible, but also notes the

\footnotetext{
${ }^{19}$ Olyan, Friendship, 5.

${ }^{20}$ Olyan, Friendship, 11-37.

${ }^{21}$ Olyan, Friendship, 38-60.

${ }^{22}$ Olyan, Friendship, 7-8, 69-76 (on David and Jonathan).

${ }^{23}$ Compare Gen 17:8; Exod 6:7; Lev 26:12; Jer 31:33.
} 
innovative appropriation of those traditions in the Hebrew version of Sirach. ${ }^{24}$ The role of friend as guide (Sir 40:23), the possibility of reconciliation between estranged friends (Sir $22: 21-22 ; 27: 21)$, and the way that material giving and generosity serve as conduits for friendly relations (Sir 14:13; 22:23) are just three examples of this innovation. Sirach provides a rich example of the ways that biblical thought is extended, deepened and transformed as a result of the encounter with Hellenistic ideas. Other texts bear witness to similar forms of cultural engagement. In 1 Maccabees the term is used with particular reference to the quest for a treaty with Rome (e.g. 1 Macc 8:1, 17; 12:1; 14:18 cf. 2 Macc 4:11). Philo's writings seem to betray knowledge of Stoic notions of friendship which serve Philo's quest for a 'Jewish universal understanding of the human race'. ${ }^{25}$ The Wisdom of Solomon portrays Solomonic wisdom as that which establishes 'friendship with God' (Wis 7:14), which in turn means that the relationship with Wisdom herself can be construed in terms of friendship (Wis 8:18). This notion of friendship with God/Wisdom is undoubtedly an intensification of traditions in the Hebrew Bible where the language of friendship to describe God's relationship to specific figures and/or the people of Israel. Isaiah 41:8 names Abraham as a 'friend of God' precisely in his role as the father of Israel (cf. 2 Chron 20:7). Although the verb used here is derived from ' $h b$, the regular verb for 'to love', the meaning 'friend' is acceptable. ${ }^{26}$ Exodus 33:11 contains the striking notion that God speaks to Moses

\footnotetext{
${ }^{24}$ Olyan, Friendship, 87-94. See also Jeremy Corley, Ben Sira's Teaching on Friendship, 316, (Providence RI: Brown Judaic Studies, 2002)

${ }^{25}$ Gregory E. Sterling, "The Bond of Humanity: Friendship in Philo of Alexandria," in Greco-Roman Perspectives on Friendship, ed. John T. Fitzgerald, SBL Resources for Biblical Study 34 (Atlanta: Scholars, 1997), 203-223, here 222.

${ }^{26}$ See the discussion in Jan Dietrich, "Friendship with God: Old Testament and Ancient Near Eastern Perspectives," Scandinavian Journal of the Old Testament 28 (2014): 157-171, here 167-168, n.36.
} 
'as to a friend'. ${ }^{27}$ Possible additional references to friendship with God can also be found in Job 16:21 and Psalm 25:14. ${ }^{28}$

The covenantal aspects of biblical friendship, the apparent willingness to talk about friendship with God, and the importance afforded to representative or mediatory figures in Jewish friendship talk (Abraham, Moses, Solomon, Wisdom) all contribute to a noticeable development from the Greco-Roman traditions. To be sure, friendship remains a social category, preserving characteristic features of unity, mutuality and reciprocity, loyalty, and sacrifice. But these 'horizontal' aspects of the friendship relationship are sometimes connected explicitly, usually via reference to human mediation, to the 'vertical' relationship between God and Israel / humanity. It is with this distinctive combination of theological and social aspects in mind that we turn to the New Testament evidence.

\section{The Pauline Letters ${ }^{29}$}

Without doubt, Paul's letters contain the most explicit and sustained use of friendship traditions in the New Testament. While recognized in earlier scholarship, perhaps more obviously trained to detect connections between Paul's writing and classical topoi, it is only in the last 30 years that the extent of Paul's interaction with friendship ideas has been fully grasped. ${ }^{30}$

\footnotetext{
${ }^{27}$ For a discussion see Jacqueline C. Lapsley, "Friends with God?: Moses and the Possibility of Covenantal Friendship," Interpretation 58 (2004): 117-129.

${ }^{28}$ For discussion see Dietrich, "Friendship," 170.

${ }^{29}$ Only a small selection of texts are singled out for mention here. A relatively comprehensive list of possible 'friendship' texts in Paul can be found in John T. Fitzgerald, "Paul and Friendship," in Paul in the GrecoRoman World: A Handbook, ed. J. Paul Sampley, (Harrisburg: Trinity Press International, 2003), 319-343, here 340.

${ }^{30}$ A strong case can be made for seeing Peter Marshall, Enmity in Corinth: Social Conventions in Paul's Relations with the Corinthians, 2/23, (Tübingen: J. C. B. Mohr (Paul Siebeck), 1987) as a pivotal work in this
} 
We turn first to Philippians which, by common consent contains the most extensive and explicit density of friendship language and themes among all of the epistles. A number of commentators have documented the significance of Paul's language of partnership (Phil 1:5, 7; 2:1; 4:14, 15), 'one soul' (Phil 1:27; cf. 2:2), 'thinking the same thing' (Phil 2:2; 4:2), as well as the strongly reciprocal tone of the letter's rhetoric, and have explained this with reference to Paul's use of friendship motifs. ${ }^{31}$ Scholarship on friendship in Philippians suffers, however, from significant confusion over the precise nature of the letter's rhetoric. While it is generally agreed that the letter opening (1:1-11) and closing (4:8-23) seem to have the relationship between Paul and the Philippian assembly in mind, the exhortations of the letter body (which at points contain friendship references) are almost always read as exhortations to unity within the Philippian community. A strong case can be made for the need to re-read the letter body of Philippians to make it clear that the friendship implied by the letter is always that of apostle to assembly and vice-versa. ${ }^{32}$ This is significant, in so far

\footnotetext{
regard. There continues to be significant debate, however, as to whether friendship is the best interpretative category for understanding Paul's relational language, given his regular use of kinship imagery, the importance of apostolic authority claims, and the possibility that other Greco-Roman concepts have influenced his rhetoric. For a perceptive study of Philippians that begins by rejecting the value of friendship for understanding the letter see Paul A. Holloway, Consolation in Philippians: Philosophical Resources and Rhetorical Strategy, Society for New Testament Studies Monograph Series 112, (Cambridge: Cambridge University Press, 2001).

${ }^{31}$ Several key essays prepared the ground for this approach to Philippians including L. Michael White, "Morality Between Two Worlds: A Paradigm of Friendship in Philippians," in Greeks, Romans, and Christians: Essays in Honor of Abraham J. Malherbe, eds. David L. Balch, et al., (Minneapolis: Fortress, 1990), 201-215, Stanley K. Stowers, "Friends and Enemies in the Politics of Heaven: Reading Theology in Philippians," in Pauline Theology: Thessalonians, Galatians, Philippians, Philemon, ed. Jouette M. Bassler, (Minneapolis: Fortress, 1991), 105-121, and the chapters by Reumann, Berry, Malherbe, and Fitzgerald in Fitzgerald ed. Friendship, Flattery, and Frankness of Speech: Studies on Friendship in the New Testament World (ed.), Part Two. Reading Philippians in the light of such traditions is now commonplace. See, for example, Gordon. D. Fee, Paul's Letter to the Philippians, New International Commentary on the New Testament (Grand Rapids: Eerdmans, 1995), Stephen E. Fowl, Philippians, (Grand Rapids / Cambridge: Eerdmans, 2005); G. Walter Hansen, The Letter to the Philippians, Pillar New Testamnt Commentary (Grand Rapids: Eerdmans, 2009). For a critical assessment of the letter's rhetoric of 'friendship' see Joseph A. Marchal, Hierarchy, Unity and Imitation: A Feminist Rhetorical Analysis of Power Dynamics in Paul's Letter to the Philippians, Academia Biblica 24, (Atlanta: Society of Biblical Literature, 2006).

${ }^{32}$ In a forthcoming monograph, provisionally entitled Philippians and Friendship: Rhetoric and Relationship in a Pauline Letter, I provide just such a reading of the letter's rhetoric, calling for the abandonment of the 'disunity' hypothesis as an adequate explanation of the letter's composition.
} 
as Paul's apostolic role in relation to the community is mediatorial in nature. The Philippians adherence to Paul's gospel, and to Paul himself as apostle, is indicative of their obedience to God (Phil 2:1-4, 12-18). ${ }^{33}$ Paul exemplifies a pattern of transformation (Phil 3:4-11), grounded in the Christ-event (Phil 2:5-11), and directed towards the ongoing and ultimate transformation of the Philippians into the image of Christ (Phil 3:12-16, 20-21). The Philippians' friendship with Paul immerses them more deeply into the new existence made possible by God's action in the death and resurrection of Christ. Although Paul does not make it explicit in Philippians, he can elsewhere configure salvation in terms that portray the overcoming of enmity and the establishment of friendship between God and humanity (see Rom 5:6-11; 2 Cor 5:11-21). ${ }^{34}$

Two features of Philippians which are closely associated with discussions of friendship in Paul's world are also discussed at some length in relation to other letters: the importance of providing material and financial support to a friend in time of need (see Phil 4:10-20), and the requirement to distance oneself from one's enemies (see Phil 3:2-3, 18-20). Both are features of Paul's complex and, at times, fraught relationship to the Corinthian church. On the one hand the question of the appropriate basis of support for Paul is clearly an issue (1 Cor 9:1-23), and Paul is deeply concerned to ensure that the Corinthians resist alternative

\footnotetext{
${ }^{33}$ See Sean F. Winter, ""Obedient to Death": Revisiting the Rhetorical Function of Philippians 2:6-11," Australian Biblical Review 63 (2015): 1-13.

${ }^{34}$ See Hans-Josef Klauck, "Kirche als Freundesgemeinschaft? Auf Spurensuche im Neuen Testament," in Gemeinde zwischen Haus und Stadt: Kirche bei Paulus, (Freiburg: Herder, 1992), 95-123 and John T. Fitzgerald, "Paul and Paradigm Shifts: Reconciliation and its Linkage Group," in Paul Beyond the Judaism/Hellenism Divine, ed. Troels Engberg-Pedersen, (Louisville: Westminster John Knox, 2001), $241-262$.
} 
authority figures (2 Cor 10-13). ${ }^{35}$ Paul's use of the motif of 'boldness' / $\pi \alpha \rho \rho \eta \sigma i ́ \alpha$ in 2 Corinthians $3: 12 ; 7: 4$ and elsewhere (1 Thess 2:2; Phmn 8). ${ }^{36}$

Galatians 4:12-20 also seems to draw on ideas related to the need to be able to identify a true friend. There, Paul describes the Galatians initial reception of the apostle as being marked by welcome, 'goodwill', and a willingness to alleviate Paul's suffering (4:13-15). Having welcomed Paul as a true friend, the Galatians should not now regard him as an enemy (4:16). ${ }^{37}$ The use of friendship language in rhetoric designed to secure a favourable reception of Paul is also found in Romans 15:14-33 where Paul informs his audience of his travel plans, in expectation of Roman hospitality on his journey west (Rom 15:22-29). ${ }^{38}$

On occasion these friendship themes are expressed by Paul using rhetorical clichés that are familiar to us from the Greco-Roman tradition. ${ }^{39}$ However in most instances it the connection lies at the conceptual level, and we do well to bear in mind that the ideas of sacrificial giving to the other, or striving for unity, are not exclusively the preserve of friendship traditions. When considered together, however, it is difficult to imagine that a $1^{\text {st }}$ century writer who construes their relationship with their audiences in these kinds of ways has not been influenced by the wider discourse of friendship that is present in the wider culture.

\footnotetext{
${ }^{35}$ For two differently configured accounts of the history of the relationship between Paul and the Corinthians see Marshall, Enmity in Corinth and L. L. Welborn, An End to Enmity: Paul and the "Wrongdoer" of Second Corinthians, Beiheifte zur Zeitschrift für die neutestamentliche Wissenschaft und die Künde der älteren Kirche 185, (Berlin: De Gruyter, 2011).

${ }^{36}$ See J. Paul Sampley, "Paul's Frank Speech with the Galatians and the Corinthians," in Early Christianity and Classical Culture: Comparative Studies in Honour of Abraham J. Malherbe, eds. John T. Fitzgerald, et al., Supplements to Novum Testamentum 110 (Leiden: Brill, 2004), 295-321.

${ }^{37}$ See Mitchell, "'Greet the Friends",'227-230.

${ }^{38}$ Benjamin J. Fiore, "Friendship in the Exhortation of Romans 15:14-33," Proceedings of the Eastern Great Lakes and Midwest Biblical Societies 7 (1987): 95-103.

${ }^{39}$ See for example the use of 'think the same thing' in 2 Cor 13:11, regularly misinterpreted and mistranslated as in the NRSV with 'agree with one another'.
} 
But all of the evidence, even that in Philippians, points to the fact that it is the relationship between apostle and audience that is in view in Paul's use of friendship topoi. This is unusual in that we are not considering a friendship between two individuals, not that between several individuals within a community, but with the friendship between an authority figure and the communities that they founded. The best explanation for this lies in the idea that Paul locates himself not merely on the horizontal axis of early Christian community relations, but crucially onto the vertical axis of the God—people of God relationship. For a $1^{\text {st }}$ century Jew, such a relationship is fundamentally covenantal in shape, and therefore Paul, as friend to his churches, proclaims and embodies the new covenant.

\section{Luke-Acts}

The use of friendship language in Luke-Acts is often overlooked. ${ }^{40}$ While in a number of cases it seems to represent little more than a respectful address (e.g. Luke 14:10) or descriptive term (e.g. Luke 7:6 Acts 10:24) there are points in the Lukan narrative where aspects of the friendship tradition seem to be deliberately evoked. ${ }^{41}$ The most explicit of these is Luke's account of the early Jerusalem community which offers an retrospective and idealized picture of the unity of the primitive church. The claim that the believers 'were together and had all things in common' (Acts 2:44; 4:32) or were 'of one mind' (Acts 4:32) provides (in a manner similar to Philippians) a specific link to common phraseology associated with friendship, and the reference to material reciprocity in the form of sharing

\footnotetext{
${ }^{40}$ Rollin Ramsaran, "Who is the True Friend?: Lukan Friendship as Paradigm for the Church," Leaven 5 (1997): Article 7, n.3. Available at http://digitalcommons.pepperdine.edu/leaven/vol5/iss2/7. Accessed 10th May 2017.

${ }^{41}$ See the discussion in Mitchell, "'Greet the Friends"," 236-257.
} 
wealth provides the most explicit evidence of the friendship relation. ${ }^{42}$ More recently, Joshua Jipp has argued that traditions of ritualized or guest-friendship illuminate the theme of hospitality to strangers in Acts $28 .^{43}$

\section{Gospel of John}

The Gospel of John regularly uses verbs of love ( $\varphi \imath \lambda \dot{\varepsilon} \omega, \dot{\alpha} \gamma \alpha \pi \alpha ́ \omega)$ and, despite popular opinion about the semantic distinctiveness of the two verbs in texts like John 21:15-19, seems to use the terms interchangeably (see John 13:23; 20:2; 21:7). Notable, however, are the explicit uses of the term $\varphi \imath \lambda$ ó in John $3: 29 ; 11: 11 ; 15: 13-15$. The latter reference gives us a clue as to how the author of the gospel appropriates friendship traditions. ${ }^{44}$ As friends of Jesus, the disciples are bound into an intimate relationship of mutual service. Jesus is the one who will 'lay down his life' for the disciples (15:13) and who reveals the will of the Father to them (15:15); the disciples are those who obey Jesus' commands (15:14), and are called elsewhere to reflect an equivalent level of sacrificial love (see John 13:14-15). These reciprocal actions are the manifestations of the love that binds Jesus to the disciples, but within the Johannine worldview, this is of course the means by which the disciples are brought into relationship with God. A clue to this dynamic is preserved in the Johannine

\footnotetext{
${ }^{42}$ Mitchell, "'Greet the Friends"," 238-239

${ }^{43}$ Joshua W. Jipp, Divine Visitations and Hospitality to Strangers in Luke Acts: An Interpretation of the Malta Episode in Acts 28:1-10, Supplements to Novum Testamentum 153, (Leiden: Brill, 2013).

${ }^{44}$ For a recent discussion of this theme see Klaus Scholtissek, ""Eine grossere Liebe hat niemand, als wenn einer sein Leben higibt für seine Freunde": (Joh 15,13): Die hellenistische Freundschaftethik und das Johannesevangelium," in Kontexte des Johannesevangelium, eds. Jörg Frey and Udo Schnelle, Wissenschaftliche Untersuchungen zum Neuen Testament 175 (Tübingen: Mohr Siebeck, 2004), 413-439 Varghese, Imagery of Love, 235-280, Martin C. Culy, Echoes of Friendship in the Gospel of John, New Testament Monographs 30, (Sheffield: Sheffield Phoenix, 2010), Takaaki Haraguchi, "Philia as Agapē: The Theme of Friendship in the Gospel of John," Asia Journal of Theology 28 (2014): 250-262.
} 
references to 'one's own' / oi ' $1 \delta 101 .{ }^{45}$ The Prologue announces that the $\lambda$ ó $\gamma \circ \varsigma$ comes to 'its own', evoking the attraction of like to like, in this case anticipating the declaration of the Word's enfleshment in the form of the Jewish Jesus. Those who believe in Jesus are the objects of divine love and are gathered into a new community (see the use of the same phrase in John 10:4, 13:1) marked by mutual love. The vertical and horizontal dimensions of Johannine theology connect with the equivalent dimensions of ancient friendship language. ${ }^{46}$ The quality of this relationship is also manifest in Jesus naming Lazarus as 'friend' (John 11:11), in the figure named as the 'disciple whom Jesus loved' (see John 13:23; 19:26; 20:2; 21:7) and, ultimately, in the restitution of Peter (John 21:15-19). ${ }^{47}$

\section{James}

Alicia Batten's recent monograph on Friendship and Benefaction in James makes a sustained case for understanding the letter of James as a text which addresses a specific social setting (the need to care for the poor in a culture of patronage) by 'drawing on the topos of

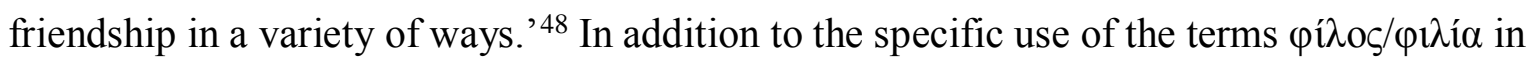
2:23 and 4:4 (the first in relation to Abraham, and the second figured negatively in relation the world), Batten shows how the themes of friendship are woven through major sections of the letter, in contrast to notions relation to patronage. For example, the likely linguistic

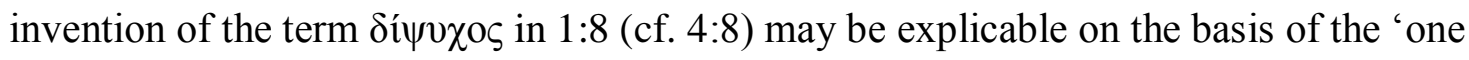

\footnotetext{
${ }^{45}$ J. Massyngbaerde Ford, Redeemer - Friend and Mother: Salvation in Antiquity and in the Gospel of John, (Minneapolis: Fortress, 1997), 118.

${ }^{46}$ And, as a number of scholars have noted, is essentially covenantal in shape. See Rekha M. Chennattu, Johannine Discipleship as Covenant Relationship, (Peabody: Hendrickson, 2006).

${ }^{47}$ On the Beloved Disciple see Ronald F. Hock, "Jesus, The Beloved Disciple, and Greco-Roman Friendship," in Christian Origins and Greco-Roman Culture: Social and Literary Contexts for the New Testament, eds. Stanley E. Porter and Andrew W. Pitts, Texts and Editions for New Testament Study 9 (Leiden: Brill, 2013), 195-212.

${ }^{48}$ Batten, Friendship, 195. For full publication details see n.6 above.
} 
mind' motif of Greco-Roman friendship. ${ }^{49}$ An emphasis on the importance of hospitality may be present in James' reference to Abraham and Rahab in 2:23-25. ${ }^{50}$ James $4: 4$ serves to characterize God as the ultimate friend and benefactor. ${ }^{51}$

\section{Conclusion}

There is no place here for over-exaggerated claims about the influence of friendship traditions on the writers of the New Testament. While we should not make the mistake of thinking that the lack of explicit friendship language means that early Christian writers were uninterested in the idea, neither should we see friendship everywhere. New Testament scholars have been carefully working to identify the places where the theology and argument of these texts seem to betray the influence of friendship traditions. In exploring some of these texts here, I have drawn particular attention to the way in which friendship language serves the wider rhetorical aims of these texts whether those be Paul's need to secure adherence to his gospel and apostolic authority, John's emphasis on Jesus' revelatory role for his own community, or James' urgent parenesis to a socially divided community. In every case, friendship between believers, or between a community and its leader, is placed into a wider relational matrix in which God is the one who establishes and sustains relationship and is, therefore, the primary benefactor. ${ }^{52}$

\footnotetext{
${ }^{49}$ Batten, Friendship, 111-114, 117-119.

${ }^{50}$ Batten, Friendship, 140-143.

${ }^{51}$ Batten, Friendship, 174-177.

${ }^{52}$ See the parallel argument in relation to patronage language in David E. Briones, Paul's Financial Policy: A Socio-Theological Approach, 494, (London: Bloomsbury, 2013).
} 
Understanding the ways in which the New Testament adopts and adapts antecedent friendship traditions from both the Greco-Roman and Jewish worlds provides us with an excellent example of the way that early Christian theology and ethics was already embedded in broader cultural values, social frameworks, and embodied practices. An awareness of these friendship motifs also helps to explicate the internal theological and rhetorical dynamics of the New Testament texts themselves. In drawing attention to the relationship between the New Testament and friendship traditions, we must remember that these texts go on to be formative in the development of the Christian tradition; one in which the idea of friendship has long been important and, after something of a hiatus, is now making something of a comeback. ${ }^{53}$

\footnotetext{
${ }^{53}$ See for example David B. Burrell, Friendship and Ways to Truth, (Notre Dame: University of Notre Dame Press, 2000); E. D. H. Carmichael, Friendship: Interpreting Christian Love, (London / New York: T \& T Clark International, 2004); Sean F. Winter and Brian Haymes, "Friendship: Find Fellow Travellers," in Forming Christian Habits in Post-Christendom: The Legacy of Alan and Eleanor Kreider, eds. James R. Krabill and Stuart Murray, (Harrionsburg VA: Herald, 2011), 117-124; Marco Hofheinz, Frank Mathwig and Matthias Zeindler, eds., Freundschaft: Zur Aktualität eines traditionsreichen Begriffs, (Zurich: Theologischer, 2014) F. Gerald Downing, "Friends in God: A Foundational Motif in Classical Reflections on the Divine Economy," Anglican Theological Review 97 (2015): 483-494.
} 